Int. J. Electrochem. Sci., 15 (2020) 3013 - 3028

International Journal of

ELECTROCHEMICAL

SCIENCE

$\underline{\text { WWW.electrochemsci.org }}$

\title{
Degradation of the Sealing Silicone Rubbers in a Proton Exchange Membrane Fuel Cell at Cold Start Conditions
}

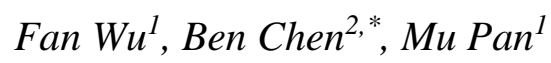 \\ ${ }^{1}$ State Key Laboratory of Advanced Technology for Materials Synthesis and Processing, Wuhan \\ University of Technology, Wuhan 430070, China \\ ${ }^{2}$ Hubei Key Laboratory of Advanced Technology for Automotive Components, Wuhan University of \\ Technology, Wuhan, 430070, China \\ *E-mail: chenben99@ whut.edu.cn
}

doi: $10.20964 / 2020.04 .54$

Received: 7 December 2019 / Accepted: 12 February 2020 / Published: 10 March 2020

The sealing performance of gaskets is important for ensuring successful cold starts and stable operation of proton exchange membrane fuel cells (PEMFCs). To simplify water and thermal management, fuel cells in cars usually operate at an elevated temperature of $90^{\circ} \mathrm{C}$. In this work, the degradation of silicone rubbers, as potential gasket materials for PEMFCs, was investigated in different cold-start processes ranging from $-5{ }^{\circ} \mathrm{C}$ to $90{ }^{\circ} \mathrm{C} ;-10{ }^{\circ} \mathrm{C}$ to $90{ }^{\circ} \mathrm{C}$; and $-20{ }^{\circ} \mathrm{C}$ to $90{ }^{\circ} \mathrm{C}$. After 200 temperature cycles, the aged silicone rubbers were cut into gaskets and assembled into a PEMFC single cell for assessments of gas leakage. The hardness of the silicone rubbers increased and their weight gradually decreased with increasing number of temperature cycles. In addition, these characteristics deteriorated with decreasing initial cycling temperature. Atomic absorption spectrometry indicated that calcium leached out from the silicone rubbers into the soaking solution. Scanning electron microscopy revealed that cracks and caves formed on the sample surfaces and the attenuated total reflection Fourier transform infrared spectra results showed that the surface chemistry was significantly changed. Importantly, the gas leakage of the PEMFC single cell showed that the sealing performance of the aged silicone rubbers changed significantly compared to that of the pristine rubbers.

Keywords: Silicone rubbers, PEMFC, cold-start process, aging, gas leakage

\section{FULL TEXT}

(C) 2020 The Authors. Published by ESG (www.electrochemsci.org). This article is an open access article distributed under the terms and conditions of the Creative Commons Attribution license (http://creativecommons.org/licenses/by/4.0/). 